\title{
EDITORIAL
}

\section{REPUBLIC OF SLOVENIA - THE FIRST TWENTY-FIVE YEARS OF INDEPENDENCE IN THE INTERNATIONAL SECURITY ENVIRONMENT}

The year 2016 was an important year for Slovenia from various different aspects. Twenty-five years have passed since Slovenia gained its independence, and for the same time period, the country has been taking care of its own security independently. As early as in 1990, the Slovenians started preparing for the big changes ahead. Two events from that time need mentioning, namely the plebiscite at the end of the year, which was important to all other activities undertaken the following year, and the historic date of 25 June 1991, when the Declaration of Independence and the Basic Constitutional Charter on the Sovereignty and Independence of the Republic of Slovenia were adopted. Slovenia's sovereignty and independence were declared the following day. On 27 June, Slovenia's War of Independence, which lasted for ten days, began with an attack launched by the Yugoslav People's Army.

In 1992, Slovenia joined the Organisation for Security and Cooperation in Europe (OSCE) and became the $176^{\text {th }}$ member of the United Nations. The democratically expressed will for accession to NATO was first clearly expressed in the amendments to the Resolution on the Guidelines for National Security in 1994. That was when Slovenia joined the Partnership for Peace programme, which initiated the journey to join that political and security organisation.

In 2003, the Slovenians decided in two consultative referendums that we wanted to create our future and safety as members of the European Union and NATO.

On 29 March, Slovenia became a NATO member state, and on 1 May, it also became a member of the European Union. The events and activities listed above are a testament to the successful development of Slovenia as an independent state, whose large amount of energy and mutual cooperation, as well as successful foreign policy and quality diplomacy, helped make remarkable progress on its rather short development path. 
Some above-mentioned activities from the fields of foreign policy and diplomacy also affect the fields of defence and armed forces. There have been numerous significant milestones in the development of the Slovenian Armed Forces.

On this occasion, I should mention 15 May 1991, when the first Slovenian conscripts started their military service on their home soil, namely in Ig near Ljubljana and in Pekre near Maribor. At the end of 1994, the Defence Act was adopted by a two-thirds majority vote, which, among other things, signified the end of the Territorial Defence and the beginning of the Slovenian Armed Forces with a capital S. In May 1995, the decision was taken to make 15 May the Day of the Slovenian Armed Forces.

In 1997, members of the Slovenian Armed Forces were deployed to the military and humanitarian ALBA operation for the first time. From then to the end of 2016, Slovenia contributed greatly to international security, since during that period, 11,357 members of the Slovenian Armed Forces were deployed to international operations and missions.

In 2003, the last generation of conscripts served their compulsory military service; after that, the Slovenian Armed Forces changed to a professional army with contractual reserves. A year later, when Slovenia became a member of NATO, the first members of the Slovenian Armed Forces left for the international ISAF operation and mission in Afghanistan.

Anton Grizold and Alojz Šteiner have written before on the subject of development periods of military defence after Slovenia gained independence. Šteiner divides the development of the Slovenian Armed Forces into four periods: the period between 1991 and 1994, which he calls the Territorial Defence period; the period between 1995 and 1999, which saw the reorganisation of the Slovenian Armed Forces and the beginning of international military cooperation; the period between 2000 and 2004, which he defines as the time of preparations for entry into NATO and the beginning of professionalisation and transformation of the Slovenian Armed Forces; and the period between 2005 and 2010, which was characterised by the integration into NATO and the European Union military structures, as well as the continuation of the transformation of the Slovenian Armed Forces. The time after 2011 and its characteristics have not been defined yet; however, it has undoubtedly been marked by the financial crisis, which has resulted in the reduction of funding for defence in most member states of the Alliance and the European Union. The Alliance has placed great importance on smart defence, niche capabilities and other activities, endorsed at the NATO Summits in Chicago in 2012, in Wales in 2014 and in Warsaw in 2016.

Several authors whose contributions have been published in the Contemporary Military Challenges have addressed topical issues after 2011, and thus contributed to the development of military defence contents. The same guidelines are followed in the current issue as well. 
In his article entitled The challenge to defense reform in Central/Eastern Europe, with reference to Slovenia, Thomas Durell Young shares his outside (i.e. American) view of defence reforms and Slovenia as part of the international environment. Has Slovenia developed modern armed forces during the past twenty-five years, and can it contribute successfully to joint capabilities in the international environment; or is there still much more to be done when it comes to defence?

The reduction in defence resources has brought about changes in the countries which are member states of the EU and the Alliance. In her article entitled New Modern Threat to National Security - Budget Threat, Vida Žurga stresses the importance of self-sufficiency of Slovenia's national security system, and how that self-sufficiency has been tested in the case of the migrant crisis.

Viktor Potočnik continues his trilogy. For this issue, he prepared the article Fourth Generation Warfare (Part 2): Comprehensive Reform of the National Security System. As he mentions, some authors have recently proposed several suggestions and expressed concerns regarding Slovenia's current national security system and the necessary changes, but nothing concrete has changed. Potočnik goes into more detail, which he presents with great clarity.

The meaning of strategic communications has been the topic of many authors. But how are strategic communications organised within NATO? The question is answered by Nina Raduha in her article Nato's Strategic Communications Concept in the Republic of Slovenia with emphasis on the Slovenian Armed Forces. It is not merely a matter for the Slovenian Armed Forces, but the state as a whole, and should be an important part of its strategic communications. But is that really the case?

Igor Prelog believes that combat aviation can be especially suitable for air support to counter-insurgency operations due to its many advantages over high-technology jet-engine combat aircraft. He discusses how Slovenia could help with counterinsurgency operations within the Alliance in his article Military aviation in counterinsurgency operations and analysis of the use of Pilatus PC-9.

Gregor Jazbec is the author of the article Psychology of combat: research on a soldier's experiencing of war and psychological consequences of combat. It is a demanding topic which deals with extreme aspects of combat. The author conducted research on experience of war and psychological consequences among soldiers participating in different wars in Slovenia, and compared his findings with similar research carried out in other states.

We hope you enjoy reading this issue and feel inspired to write an article yourself. 